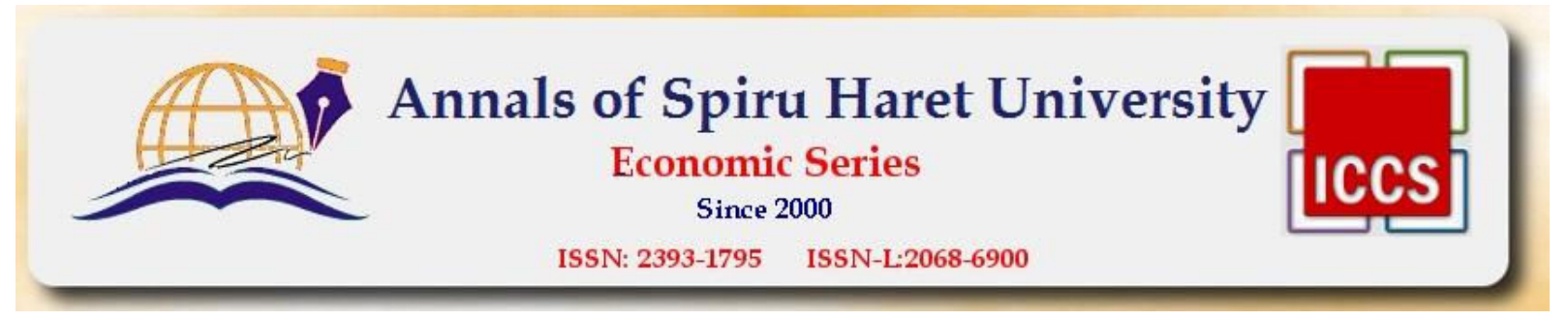

Issue 4/2016

\title{
OPERATIONS OF INTERNATIONAL CRISIS MANAGEMENT AS A PART OF SECURITY AND DEFENSE POLICY OF THE REPUBLIC OF BULGARIA
}

\author{
Elitsa PETROVA ${ }^{1}$, Nikolay NICHEV ${ }^{1}$ \\ ${ }^{1}$ National Military University, Bulgaria, Veliko Tarnovo, \\ E-mail: nicheff@abv.bg
}

\begin{abstract}
The current scientific publication follows the invitation of scientists from the University of Defense in the Czech Republic, Brno for joint international study on economic diplomacy and peacekeeping. The paper presents the role of the Bulgarian army in the operations of international crisis management as part of the security and defence policy of the country, and characteristics of the activities of armed forces in international operations for crisis management. The article focuses on national contribution to international efforts in support of peace and stability, the legal basis for the participation of the Armed Forces of the Republic of Bulgaria in allied and coalition operations and support operations and military participation of the Republic of Bulgaria in international missions and operations.
\end{abstract}

Keywords: crisis management, international crisis management, Armed Forces of the Republic of Bulgaria.

JEL Classification: $\mathrm{H} 12$

\section{Introduction}

The Republic of Bulgaria is involved in the collective EU members' effort, coordinated for the effective implementation of policies and mechanisms in the field of international relations. The common security and defence policy has to contribute to the strengthening of transatlantic cooperation. The country develops its national capacity to participate in the common security policy of the EU by participation in operations and missions for crisis management.

The Republic of Bulgaria aims at promoting and strengthening the role of NATO in the implementation of policy and operational responsibilities to continuation of political dialogue and successful participation of the country in operations and NATO missions, through participation in international crisis management.

National contribution to international efforts in support of peace and stability

National contribution to international efforts in support of peace and stability includes participation in allied and coalition operations with formations of the Armed Forces. Armed Forces and institutions, which provide international crisis management are focused in developing and maintaining a common security and defence policy through participation in missions and operations for strengthening the international order and security.[1]

The powers of the President in the implementation of international crisis management policy are defined in the Constitution and the laws of the country. The President is the supreme commander of the Armed Forces and Head of Consultative Council on National Security.

The Consultative Council on National Security forms the political advisory level in the system for international crisis management. Its role is to build a broad public consensus on issues of national security and in particular on issues of the international crisis management. 


\section{Annals of Spiru Haret University \\ Economic Series \\ Since 2000}

ISSN: 2393-1795 ISSN-L:2068-6900

\section{Issue 4/2016}

Central executive authorities perform the implementation of international crisis management policy. Ministers, heads of departments and governors of districts are responsible for the state of international crisis management within their field of competence. [2]

The role of the Armed Forces as an instrument of this policy is to contribute to the realization of national interests, to deter and defeat enemy together with allied forces, to keep threats away from the borders of the country, and contribute to the protection of the international peace and security. In terms of international crisis management, the Armed Forces are assigned to perform the mission "support of international peace and security". This mission includes the fulfilment of international commitments and participation in NATO and the European Union in crisis response, conflict prevention, combating terrorism, participation in missions of the UN, and other coalition formats, activities for control of weapons of mass destruction, their delivery and materials for their production, international military cooperation, humanitarian aid, etc.

The political ambition of the Bulgarian Armed Forces for the mission "Support of international peace and security" is to maintain readiness for participation in multinational allied and coalition operations in response to crises. This contribution includes participation in long-term operations with rotation with a reinforced battalion (combat group) or a number of small units, but within resources equivalent to the level of ambition (about 1.000 people). Naval Forces are involved with the declared resources equivalent to one frigate for a period of three to six months in a year. The Air Force participates with helicopters without rotation of personnel and for a period of six months in a year. The necessary logistical support is also provided. [3]

The elements of management of the Bulgarian system for participation in international crisis operations are:

- analysis and assessment of the status and trends in the security environment and taking preventive action;

- adequate exchange of information;

- planning, preparation and management of performance;

- implementation of a broad and systematic institutional approach;

- coordination in the work of relevant institutions and organizations;

- methodology and methods for assessing the international crisis management and its components in relation to their resourcing and required results;

- mechanisms to assess the taken actions and achieved results;

- establishing a system of internal control and correction for international crisis management.

Essential elements of the international crisis management are consultative bodies to the Council of Ministers. They coordinate the operational implementation of the state policy and provide the necessary concealing to the Government and the relevant authorities in the preparation and implementation of decisions within their competence.

The Security Council is an advisory and coordinating body to the Council of Ministers, which offers a solution for determining the strategic objectives of the executive bodies of the system of international crisis management. The Security Council provides solutions for crisis management, coordinate planning resources to achieve synergy in their use, and coordinate the implementation of the taken decisions. The Council organizes and monitors the implementation of international crisis management. [4]

The legal basis for the participation of the Armed Forces of the Republic of Bulgaria in allied and coalition operations and support operations

The legal basis for the participation of the Armed Forces of the Republic of Bulgaria in allied and coalition operations and support operations is art. 84, item 11 of the Constitution of the Republic of Bulgaria, under which deployment of forces abroad is possible only with the permission of the 


\section{Annals of Spiru Haret University \\ Economic Series \\ Since 2000 \\ ISSN: 2393-1795 ISSN-L:2068-6900}

Issue 4/2016

National Assembly at the proposal of the Council of Ministers. Any particular participation in such operations requires a separate decision. [5]

Regulatory framework defining the opportunities and mechanisms for participation of our country in efforts to maintain peace includes the National Concept for Bulgaria's participation in peacekeeping operations, developed in 1994, and The Law for Defense and Armed Forces of the Republic of Bulgaria.

According to the concept for participation in peacekeeping operations, Bulgarian participation is subject to the following objectives:

- to raise the international prestige of the Republic of Bulgaria through active participation in efforts to prevent and peaceful settlement of conflicts;

- to integrate the Republic of Bulgaria in European security structures through participation in cooperation with NATO and EU with mandate of the UN or mandate of the Organization for Security and Cooperation in Europe (OSCE);

- to prepare highly qualified specialists in the field of peacekeeping operations and cooperation in military sphere;

- to acquire new military experience for the preparation of the national armed forces.

The participation of Bulgarian forces and military professionals in TSO enforces the principle that all participation in an operation has to comply with the national interests of the Republic of Bulgaria. Participation can only be in operations carried out under the auspices and control of the UN or the OSCE, in accordance with the UN Charter and international law. Participation has to do with conflict prevention, and peacekeeping, and has to be based on a specific agreement with the Bulgarian government for every specific military operation.

Military participation of the Republic of Bulgaria in international missions and operations

The Armed Forces of the Republic of Bulgaria participate in international missions and operations as separate units or as individual soldiers in a specific mission or operation. Figure 1 shows the participation of Bulgarian military personnel in international missions and operations.

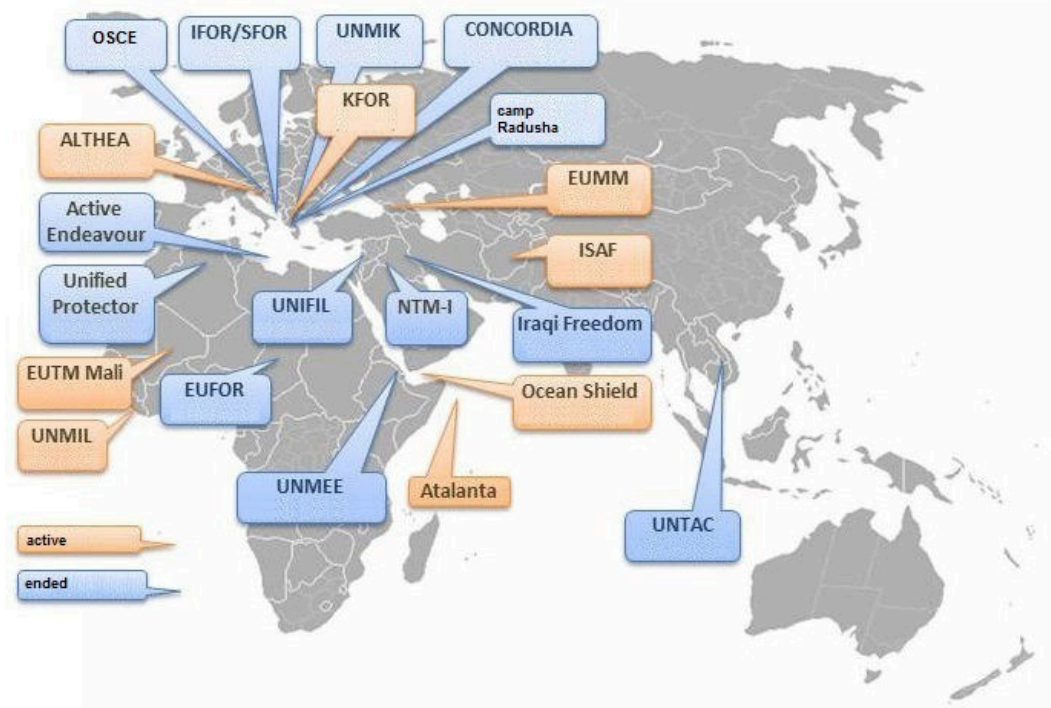

Figure no. 1. Military participation of the Republic of Bulgaria in international missions and operations [6] 


\section{Annals of Spiru Haret University \\ Economic Series \\ Since 2000}

ISSN: 2393-1795 ISSN-L:2068-6900

\section{Issue 4/2016}

\section{Completed participation}

NATO stabilization force in Bosnia and Herzegovina (SFOR). Engineers, transport and mechanized platoon and a security company from the Bulgarian Army participated in SFOR.

An engineering platoon with 36 personnel participated as a component of the Dutch contingent from June 20, 1997 to November 1, 2001. Bulgarian soldiers together with their Dutch counterparts repaired and constructed public buildings and roads.

A transportation platoon participated in the composition of the group Gelb/ BELUGA from June 20, 1998 to January 15, 2001 with 26 military personnel and 10 vehicles. Bulgarian military performed transportation tasks in shipping supplies, humanitarian aid, fuel, construction of replacement temporary bridges, etc. Seven soldiers served in SFOR headquarters from August 1998 until the end of the operation.

A mechanized platoon with strength of 38 soldiers and equipment was included in the Dutch contingent on November 13, 2001. It performed real operational tasks such as patrolling and controlling.

A security company with 149 soldiers and equipment was included in the operation on January $2,2002$.

Operations of NATO in Libya (Unified Protektor). A Bulgarian frigate took part in the NATO operation "Unified Protektor" in support of the embargo against Libya. The frigate was included in operation for three months with personnel of 160 people, including special operations group of 12 soldiers.

NATO Training Mission in Iraq (NTM-I). NATO Training Mission in Iraq was launched on August 14, 2004 at the request of the Iraq government to provide concrete assistance in training and equipping of Iraqi security forces. In its essence NTM-I did not have battle nature. It is a separate operation, complementing other international efforts to rebuild Iraq. Our country participated in periodic missions with military instructors depending on particular needs.

NATO operation in the Mediterranean (Active Endeavour). Since 2005 Bulgaria has participated annually for a period of one month in the operation with a frigate with crew of about 110 people and a group of special marine squad for Marine Force Control of Ships. The mission of the frigate included the monitoring of shipping in the area of responsibility and inspection of the ships and cargo.

Multinational forces in Iraq (IRAQI FREEDOM). Bulgarian military contingent in the Multinational Force in Iraq was sent by with a decision of the Bulgarian National Assembly as of 29 May 2003. It endorsed the participation of Bulgaria in the fourth phase of the operation in Iraq "Stabilizing and recovery".

Pursuing this decision, five infantry battalions, each consisting of up to 500 soldiers, participated in the mission in Iraq. Bulgarian contingent was included in the composition of the Multinational Division "Center-South" under Polish command, with the task to provide support for the restoration of civilian facilities in the town of Karbala, and in the fall of 2004 - in the province of Diwaniyah.

The decision of the National Assembly as of May 5, 2005 stated that the military personnel be set to 400 soldiers. By a decision of 22 February 2006, the National Assembly authorized deploying Bulgarian military contingent in a humanitarian mission to guard the temporary custody and protection in camp "Ashraf". The contingent consisting of up to 155 military personnel, included security company of 120 soldiers and support national element of 35 soldiers. Until July 2008 three rotations of the contingent were made at camp "Ashraf".

For the entire period of participation in the operation in Iraq - from 22 August 2003 to 20 December 2008 -, Bulgaria rotated 11 contingents with 3.367 people altogether.

UN mission Lebanon (UNIFIL). The frigate "Daring" took part in the naval component of the UN Interim Force (UNIFIL) from October 15, 2006 to December 15, 2006. 


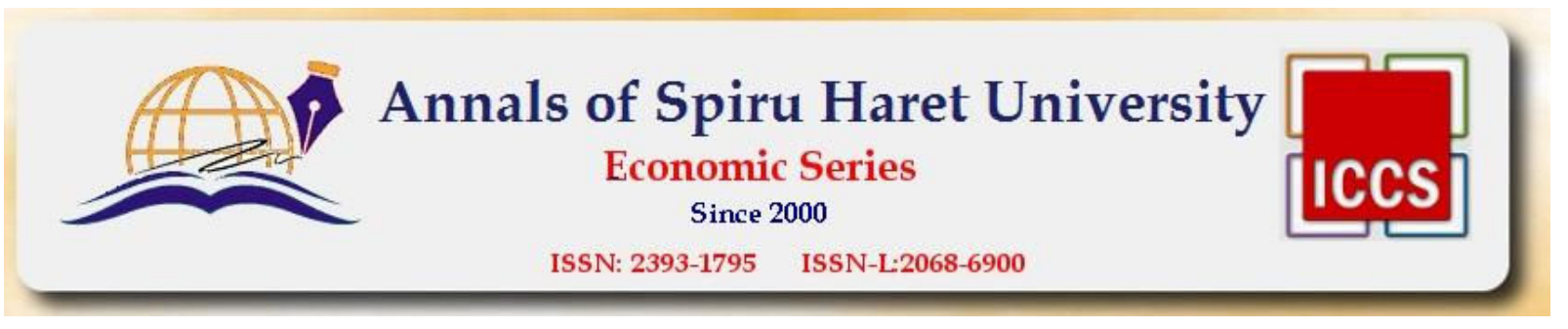

Issue 4/2016

Mission of the Organization for Security and Co-operation in Europe in the Republic of Croatia (OSCE). Bulgarian officers participated in the mission of OSCE with demining activities on the territory of Croatia in the period September 1999-April 2001.

Bulgarian military field hospital in Radusha. Implementing the commitments of the Republic of Bulgaria to provide humanitarian assistance to refugees in the Republic of Macedonia, Bulgarian military field hospital was deployed in April 1999 in the refugee camp "Radusha". Families with about 900 children, including more than 100 infants up to 1 year, and neonates in a few days were accommodated in the camp. The hospital included surgery, resuscitation, therapeutic, pediatric, psycho-neurological and infectious teams, an epidemiologist and a pharmacist. The Ministry of Defence also sent groups for logistic support with the ask to feed the refugees in Macedonia.

UN operation in maintaining the peace in Cambodia (UNTAC). Bulgarian army participated in UNTAC from 4 May 1992 to 27 November 1993 with an infantry battalion of 850 men, 10 officers to work in the headquarters of the mission, 34 military observers, and military police team of 11 people.

\section{Current missions and operations}

International forces to maintain security in Afghanistan (ISAF). On February 16, 2002 the first Bulgarian military contingent for sanitization, consisting of 32 Bulgarian soldiers was formed. It was located near the British contingent, $10 \mathrm{~km}$ from Kabul, where the banned-washing complex was deployed. A decision of the National Assembly terminated its participation and authorized the participation of a mechanized platoon and instructors to train the Afghan Army. In 2007, Bulgaria gradually increased its participation by sending two more companies: one - as part of the Italian Battle Group in Kabul, and the other - for the internal security of the perimeter of Kandahar Airport, as well as specialists in air traffic at Kabul airport, instructors, reconnaissance groups, military police, etc.

In November 2009, the mechanized company and the security platoon were withdrawn from the area of operation. In 2009, the Bulgarian company was tasked with guarding the outer perimeter of Kabul airport. At the beginning of 2009, Bulgaria sent in Kandahar a group for training the Afghan National Army. In 2011, our country sent three groups (two in Kabul and one in Kandahar) and a Team of Senior Advisors. The Republic of Bulgaria was actively committed to provide medical teams for the operation, and in 2004 sent to Kabul the first surgical team to work in the Spanish field hospital and later expanded its participation with sending Bulgarian nurses with surgical teams in Herat and Kandahar. In September 2012, four groups for training and liaison with the Afghan National Army were transformed in Advisor teams.

NATO mission in Kosovo (KFOR). On February 8, 2000, a Bulgarian engineering squad of 40 people took part in the construction, maintenance and repair of engineering equipment, as well as in the reconstruction of buildings for the needs of the local population. Bulgarian military observers participated in the mission of UN peacekeeping in Kosovo (UNMIK) from January 15, 2000. At the end of 2009, our engineering platoon terminated its participation in the operation. Bulgarian participation in KFOR amounted to 11 soldiers in the headquarters of the mission.

Military operation in Bosnia and Herzegovina (EUFOR “ALTHEA”). Bulgaria has participated in the operation with up to 10 soldiers in the headquarters and a company with a national support element of 140 soldiers and up to 40 pieces of equipment since the beginning of September 2012.

EU mission to train the security forces of Mali (EUTM mali). The Bulgarian Armed Forces has participated in EUTM Mali medical team with four soldiers with their personal weapons and equipment. 


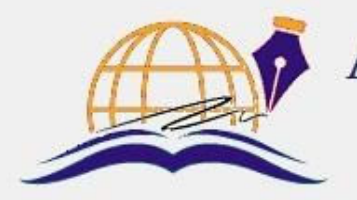

Annals of Spiru Haret University

Economic Series

Since 2000

ISSN: 2393-1795 ISSN-L:2068-6900

Issue 4/2016

Table no. 1. Participation of Bulgaria with individual military staff in operations and missions abroad

\begin{tabular}{|l|c|l|}
\hline \multicolumn{1}{|c|}{ Missions and Operations } & Numbers & \multicolumn{2}{|l|}{ Form of participation } \\
\hline $\begin{array}{l}\text { EU operation in Chad / Central African Republic } \\
\text { (EUFOR) }\end{array}$ & 2 & $\begin{array}{l}\text { headquarters of the } \\
\text { operation }\end{array}$ \\
\hline UN Mission in Ethiopia and Eritrea (UNMEE) & 7 & military observers \\
\hline An EU peacekeeping in Macedonia (CONCORDIA) & 1 & $\begin{array}{l}\text { headquarters of the } \\
\text { operation }\end{array}$ \\
\hline Military Observers in Tajikistan (UNMOT) & 27 & military observers \\
\hline $\begin{array}{l}\text { Military observers in Angola (UNAVEM III and } \\
\text { MONUA) }\end{array}$ & 38 & military observers \\
\hline EU Monitoring Mission in Georgia (EUMM) & 12 & military observers \\
\hline $\begin{array}{l}\text { EU naval operation against piracy off the coast of Somalia } \\
\text { and the Gulf of Aden (Atalanta) }\end{array}$ & 1 & operational headquarters \\
\hline UN Mission in Liberia (UNMIL) & 2 & military observers \\
\hline $\begin{array}{l}\text { NATO anti-piracy mission off the coast of Somalia and } \\
\text { the Horn of Africa "OCEAN SHIELD" }\end{array}$ & 1 & $\begin{array}{l}\text { headquarters of the } \\
\text { operation }\end{array}$ \\
\hline
\end{tabular}

\section{Conclusion}

Policy on the risks and threats facing national security and ensuring the security of citizens and democratic institutions are an integral part of the joint efforts of the EU and NATO, which lead to the realization of the vision of an area of freedom, security and justice. Bulgaria has to participate actively in international crisis management, under the auspices of the UN, EU and NATO, in fulfilling its strategic priorities to build a stable and democratic country.

The realization of the pointed missions and operations corresponds to the view expressed in the White Paper of the Armed Forces for participation of the Republic of Bulgaria in operations and missions abroad in support of international peace and security.

\section{References}

1. Petrova, Elitsa; Nichev, N., "Financing and place of the Bulgarian army in the operations of international crisis management", Revista Academiei Fortelor Terestre, no. 3 (75)/2014, Sibiu, Romania, "Nicolae Balcescu" Land forces academy, p. 309, 2014.

2. National Security Strategy of the Republic of Bulgaria. [online] [2013-12-16]. Available at:http://www.mi.government.bg/en/themes/bulgaria-s-national-security-strategy-904-300.html.

3. White Paper on Defence and Armed Forces of the Republic of Bulgaria 2010. [online] [201312-16]. Available at: <http://www.md.government.bg-/en/doc/misc/20101130_WP EN.pdf>

4. National Security Strategy of the Republic of Bulgaria. [online] [2013-12-16]. Available at: http://www.mi.government.bg/en/themes/bulgaria-s-national-security-strategy-904-300.html.

5. Legal basis for the participation of the Armed Forces of the Republic of Bulgaria in allied and coalition operations and operations in peacekeeping. [online] [2017-01-14]. Available at: http://bginnato.mfa.bg-/bulgariainnato_Participation_Missions Operations.html

6. Ministry of Defense of the Republic of Bulgaria, Missions and Operations Involving the Armed Forces of the Republic of Bulgaria. [online] [2017-01-14]. Available at: https://www.mod.bg/bg/tema_MissionsOperations.html 